\title{
Development and validation of the Logical Model of the Neonatal Hearing Screening Program
}

\author{
Marcella de Carvalho Ramos Pimentel ${ }^{1}$ \\ https://orcid.org/0000-0003-4277-6205 \\ Nilcema Figueiredo ${ }^{1}$ \\ https://orcid.org/0000-0001-6181-8728
}

Maria Luíza Lopes Timóteo de Lima1 https://orcid.org/0000-0001-8600-0017

Universidade Federal de Pernambuco UFPE, Recife, Pernambuco, Brasil.

Conflict of interests: Nonexistent

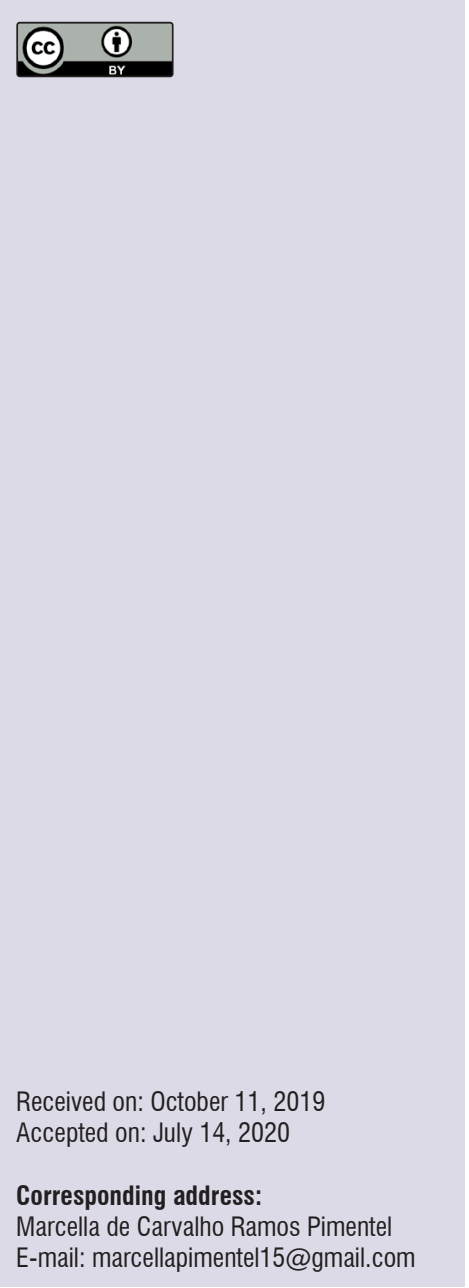

\section{ABSTRACT}

Purpose: to develop and validate the logical model of the Neonatal Hearing Screening Program in the hearing health network.

Methods: a methodological developmental research aimed to build the logical model of the Neonatal Hearing Screening Program and validate its content through a "consensus conference". The research was carried out in three stages: 1) Literature review, analysis of the normative documents, and official recommendations regarding the Neonatal Hearing Screening; 2) Development of the logical model; 3) Validation of the logical model through rounds of consultation with specialists.

Results: based on the documentary analysis, the logical model was designed in three dimensions: (1) Education in Hearing Health, (2) Neonatal Hearing Screening, and (3) Administration. It was validated based on the judgment of specialists in the field. After the validation process, three variables in the "process" and one in the "structure" aspects, were adjusted, whereas another two aspects in "process" were excluded.

Conclusion: the logical model presented the dimensions, activities, and results of the Neonatal Hearing Screening Program in practical and clear terms. Hence, it is useful not only to communicate and announce its results, but also to offer support to future evaluative research in the field of neonatal hearing health.

Keywords: Theoretical Models; Neonatal Screening; Hearing; Validation Studies 


\section{INTRODUCTION}

The importance of universal neonatal hearing screening (UNHS) has been recognized in Brazil and in the world. It is the first step to provide an opportune diagnosis of child hearing loss and it is the starting point of the hearing health care process. It is responsible for the early detection of hearing losses, ensuring that newborns (NB) who failed the screening are diagnosed and/or monitored through referrals to other levels of health care ${ }^{1-8}$.

Given its relevance, it is necessary to periodically evaluate whether the neonatal hearing screening program (NHSP) is actually achieving its objectives, for the benefits of the UNHS to be fully perceived and quantified $d^{4,9}$.

The Brazilian Federal Law 12.303/ 2010 makes it mandatory that all maternities in the country perform the infant hearing screening test free of charge, with evoked otoacoustic emissions (EOAE). Nevertheless, up to the present moment, no validated instruments have been found in Brazil to evaluate either the NHSP or the integration of its actions with primary health care and the specialized high-complexity hearing health care services, as recommended by the Ministry of Health?

Furthermore, there is neither a national databank to report the results of implementing the NHSP, nor a national program to early detect hearing losses in Brazil, as it happens in other countries ${ }^{4,9}$.

Developing and validating an instrument to evaluate the neonatal hearing screening services can contribute to the Evaluation of Health Programs and Projects and direct evaluations which, if regularly conducted, can help in decision-making and monitoring of implemented actions ${ }^{10,11}$.

A validated instrument can also be the basis for research in the field, helping to know better the evidence of the contributions brought by the NHS to the early diagnosis and intervention of hearing loss. Moreover, it aids in the acquaintance with the difficulties faced in local speech-language-hearing care. Hence, future negotiations with the government can be attained to reorganize and improve the NHSP, counting with the cooperative actions of the network, permeated by the flexibility in the organization of the services, respect for the users, and interdisciplinary work ${ }^{12}$.
To this end, when speaking of evaluating a program, it is necessary that the one making the evaluation get deeply acquainted with its short-, medium-, and long-term objectives and monitor the components - structure, process, and results -, as each one of these has useful information to judge the quality of the service. Hence, they can verify what has already been accomplished, to have the means to plan future interventions, and put them into practice ${ }^{11-16}$.

The logical model (LM) is a visual scheme that conceptualizes the links between the structures, processes, and results the program intends to achieve. It can be the first step in planning an evaluation ${ }^{13-16}$. It has been put into use since the late 1960s in other countries. In Canada, for instance, since the early 1980s, the government requires that logical models be developed to evaluate federal interventions ${ }^{14,15}$.

Developing an LM makes it easier to plan actions and manage the program itself, offering the administrators a detailed view of its implicit aspects, describing the main elements the program needs to have to work properly, following the program's objectives and the established goals ${ }^{13-16}$

This study aimed to develop and validate a logical model of the Neonatal Hearing Screening Program in the hearing health care network.

\section{METHODS}

This study was approved by the Research Ethics Committee of the Universidade Federal de Pernambuco/ Centro de Ciências da Saúde - UFPE, PE, Brazil, under the evaluation report no. 2.695.541.

This qualitative research is a three-stage methodological development aiming to create and validate a logical model of the Neonatal Hearing Screening Program.

In the first stage, documentary research was carried out regarding the Neonatal Hearing Screening Program, reviewing the specialized literature, the normative references of the Sistema Único de Saúde (SUS, the Brazilian public health care system), and the national legislation on the subject to design the logical model ${ }^{13,17-19}$. The normative documents and official recommendations used to design the logical model are shown in Figure 1. 


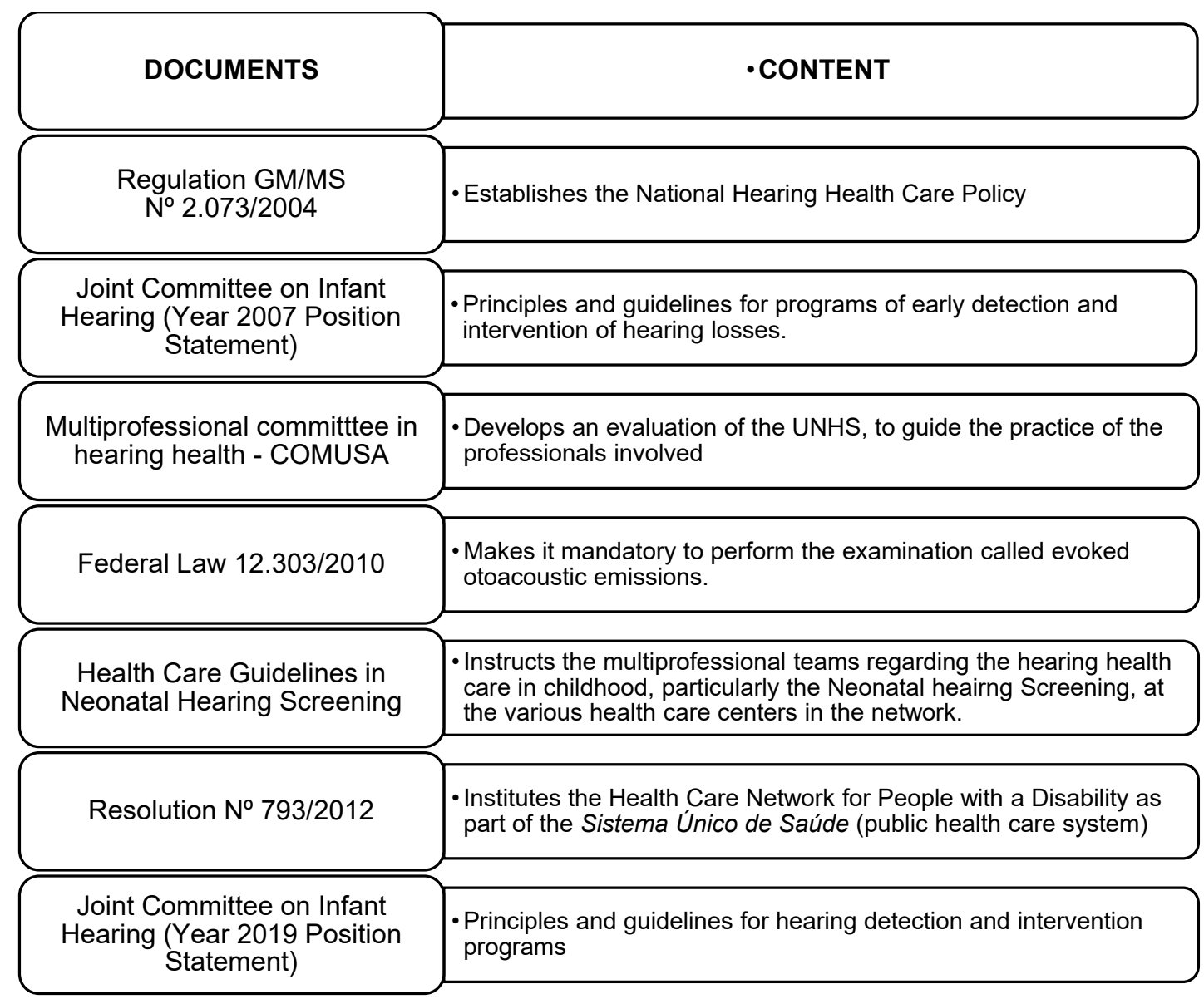

Source: Author of the research (2019).

Figure 1. Documents guiding the organization and structure of the Neonatal Hearing Screening services

The selected documents described the program's goals, objectives, principles, and activities. A script was followed for in-depth reading, considering the following questions: What problems were faced in the NHSP, and what were their possible causes and consequences? Who is the program's target audience? What components best represent it? What activities are necessary to put an intervention into practice? What are the available and necessary resources to achieve the program's objectives? What results can be achieved in the short, medium, and long run?

In the second stage, after analyzing all the program's data in light of the question script, a provisional logical model was developed containing dimensions, subdimensions, structure, process, and results expected from the Neonatal Hearing Screening Program. The dimensions worked on at first in the LM were education in hearing health, neonatal hearing screening (with identification of risks, tests, and retest as subdimensions), and administration.

In the third stage, the preliminary LM was submitted for content validation. Specialists were consulted with the "consensus conference" technique, proposed by Souza, Vieira da Silva and Hartz ${ }^{20}$, a process structured in three rounds of consultations. Its purpose is to obtain a collective and qualified opinion on specific issues until a consensus is achieved ${ }^{16,19-22}$.

For this stage, a group of four specialist speechlanguage-hearing pathologists was selected. They were invited based on their involvement with the NHSP or health policies, experience in the field of neonatal hearing screening, and published research. Six specialists were invited, selected at first by convenience sampling, and afterward according to the inclusion criteria. The specialists were selected considering their experience in research, teaching, working directly with the NHS in public and private hospitals and maternities in Alagoas and Pernambuco, Brazil. Three of them had a doctor's degree and one, a specialization certificate. Of the six specialists invited, four agreed to participate and were considered for the study. There is no consensus on either the number of judges for validation research or its inclusion criteria. The group is formed depending on the phenomenon being studied and the availability 
of participants who accept to contribute to the research. Thus, it was formed by convenience sampling, considering the guidelines by Pasquali $(1998)^{23}$, who suggests that at least six judges participate in each stage of the validation process.

Each specialist was sent an invitation e-mail with a research presentation letter (invitation letter), containing the list of documents that directed and grounded the development of the LM. It also had the provisional NHSP logical model for them to get acquainted with and analyze beforehand, and instructions on how each specialist was expected to evaluate it.

The first round had the remote participation of the researchers. It consisted in taking an overall look at the proposed NHSP logical model sent them via e-mail, individually and independently evaluating the items, analyzing each item's quality and importance, writing their qualitative suggestions beside each item, and, if necessary, making changes and proposals to be presented in the face-to-face meeting. The items in the logical model were dimensions, structure, subdimensions, process, results, and impacts.

The second round took place in a face-to-face meeting when all the specialists signed the informed consent form (ICF). Lynm ${ }^{24}$ states that in a validation process there can be five or fewer specialists; when this is the case, it is recommended that everyone agree regarding the content validity for it to be considered a reasonable representation of the potential range of classifications.

The preliminary NHSP logical model was presented, point by point, with the effective participation of the invited specialists, who had the opportunity to bring forward their opinions, observations, questions, and suggestions from the first round. This open discussion contributed not only to exchange information but also to mature the opinions based on critical thinking and systematized ideas. Hence, the group consensus made the decision-making easier.

The researcher recorded the meeting in audio upon the participants' consent. The answers, ponderings, and suggestions brought up during the meeting were qualitatively analyzed. The researcher analyzed the answers during the meeting and afterward, verifying the notes handed by the specialists at the end of the discussion, besides repeatedly revisiting and analyzing the meeting through the recording. After the results had been evaluated, a new LM was proposed, incorporating the suggestions presented by the participants.

In the third round, also remote, the logical model was resent via e-mail to the four researchers who participated in the face-to-face meeting for them to know the final result and offer new considerations about the material presented. Since no new proposals were made, it was considered as a consensus on the model presented.

\section{RESULTS}

The logical model of the Neonatal Hearing Screening Program, after analyzing the documents, was developed in the following dimensions: Education in Hearing Health (with no subdimensions), Neonatal Hearing Screening (whose subdimensions were identification of the risks, test, and retest), and Administration.

The consensus was achieved in the aspects of dimension, subdimension, structure, process, results, and impact.

After the researchers had analyzed the LM, the variables unanimously considered important remained in it.

Hence, in the total, three variables in "process" and one in "structure" were adjusted. Two variables were excluded from "process" - the first, in Neonatal Hearing Screening, "identification of the risks" subdimension: "Hearing monitoring of all neonates and infants with risk indicators for hearing loss (RIHL)"; the second, in Administration: "Execution of the Neonatal Hearing Screening Program".

Moreover, one of the specialists suggested two subdimensions to be included in Education in Hearing Health: 1) "Diagnosis of the community", and 2) "Instructive actions". Another specialist proposed that the activity "Instruct and welcome the parents in all stages of the program" be included in the "Instructive Actions" subdimension. The whole group came to a consensus regarding these inclusions.

The logical model resulting from the validation process is presented in Figure 2, comprising the three dimensions: (1) Education in Hearing Health, encompassing the "Diagnosis of the community" and "Instructive actions" subdimensions; (2) Neonatal Hearing Screening, with the three subdimensions: identification of the risks, test, and retest; (3) Administration. 


\begin{tabular}{|c|c|c|c|c|c|}
\hline DIMENSIONS & $\begin{array}{c}\text { SUB } \\
\text { DIMENSIONS } \\
\end{array}$ & $\underline{\text { STRUCTURE }}$ & PROCESS & $\begin{array}{c}\text { RESULTS } \\
\text { (short/medium) }\end{array}$ & $\begin{array}{l}\text { IMPACT } \\
\text { (long run) }\end{array}$ \\
\hline \multirow{5}{*}{ 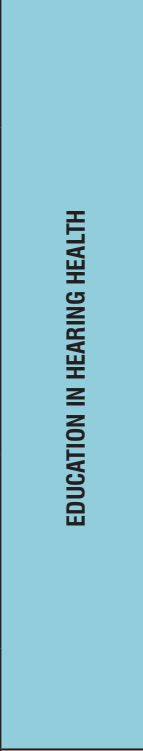 } & 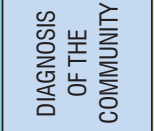 & \multirow[t]{5}{*}{$\begin{array}{l}\text { Settings to } \\
\text { develop the } \\
\text { actions. }\end{array}$} & $\begin{array}{l}\text { - Mapping the risk indicators for hearing loss (RIHL) } \\
\text { in the community. }\end{array}$ & $\begin{array}{l}\text { - Directing the hearing health actions according to the } \\
\text { specificities of the population for whom they are meant. }\end{array}$ & \multirow{11}{*}{$\begin{array}{c}\text { Maximization } \\
\text { of linguistic } \\
\text { competence, } \\
\text { biopsychosocial } \\
\text { development, } \\
\text { and literacy learning } \\
\text { in children } \\
\text { with deafness } \\
\text { or hearing loss. }\end{array}$} \\
\hline & \multirow{4}{*}{ 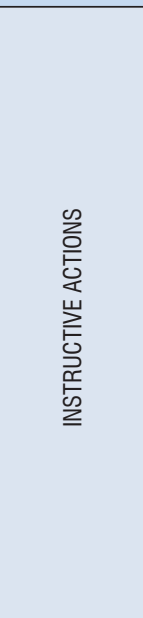 } & & $\begin{array}{l}\text { - Posting information in maternities, outpatient centers, } \\
\text { and primary health care (PHC) regarding the RIHL, } \\
\text { and the importance of immunization, continuing } \\
\text { the prenatal care, and performing the NHS to early } \\
\text { detect hearing loss (HL). }\end{array}$ & - Greater knowledge available to the population. & \\
\hline & & & $\begin{array}{l}\text { - Conducting conversation circles with the health } \\
\text { professionals working at the maternities, outpatient } \\
\text { centers, PHC, Family Health Strategy, and } \\
\text { Extended Family Health Care Center regarding } \\
\text { the importance of the NHS. }\end{array}$ & $\begin{array}{l}\text { - Increased integrated work involving the disciplines and } \\
\text { sectors and the collective practices in hearing health } \\
\text { problem- solving. }\end{array}$ & \\
\hline & & & $\begin{array}{l}\text { - Conducting conversation circles with groups of } \\
\text { pregnant women and their relatives. }\end{array}$ & $\begin{array}{l}\text { - Increased level of autonomy and awareness of } \\
\text { pregnant women and their relatives regarding the } \\
\text { importance of early detecting hearing loss for the } \\
\text { baby's hearing and language development, of sharing } \\
\text { the responsibility for the necessary hearing health care } \\
\text { of the newborn in the first years of life. }\end{array}$ & \\
\hline & & & $\begin{array}{l}\text { - Instructing and welcoming the parents in all the } \\
\text { stages of the program. }\end{array}$ & $\begin{array}{l}\text { - Humanized health care and adequate procedures, } \\
\text { considering each baby's individuality and the specific } \\
\text { needs of each family cared for. }\end{array}$ & \\
\hline \multirow{6}{*}{ 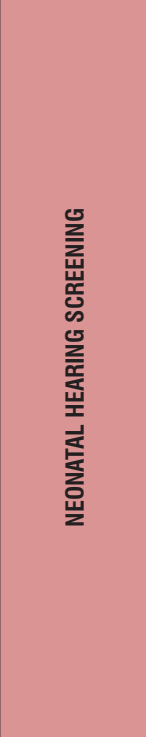 } & 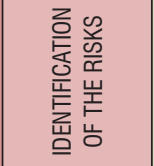 & databank. & $\begin{array}{l}\text { - Identifying the RIHL with anamnesis and } \\
\text { consultations to the medical records. }\end{array}$ & $\begin{array}{l}\text { - Adequate interventions according to each baby and } \\
\text { their family's specificities. }\end{array}$ & \\
\hline & \multirow{5}{*}{ 点 } & \multirow{5}{*}{$\begin{array}{c}\text { Human } \\
\text { resources: } \\
\text { Speech- } \\
\text { language-hearing } \\
\text { therapists, } \\
\text { physicians, health } \\
\text { administrators, } \\
\text { primary } \\
\text { health care } \\
\text { professionals. }\end{array}$} & $\begin{array}{c}\text { - Examine all the newborn babies with otoacoustic } \\
\text { emissions after the first } 24 \text { hours of life and before } \\
\text { hospital discharge. }\end{array}$ & - Early detection of cochlear hearing losses. & \\
\hline & & & - Examining all the babies that has RIHL with A-BAEP. & $\begin{array}{l}\text { - Decrease in unnecessary referrals for retest and } \\
\text { diagnosis, and elimination of false-positive results. }\end{array}$ & \\
\hline & & & $\begin{array}{l}\text { - Recording the result of the test in the baby's medical } \\
\text { record, Child Health Booklet, and available databank, by } \\
\text { the professional who examined the baby. }\end{array}$ & $\begin{array}{l}\text { - Referrals and instructions adequate to continuing the } \\
\text { health care. }\end{array}$ & \\
\hline & & & $\begin{array}{l}\text { - Offering humanized health care and informing } \\
\text { the result of the test to the parents/guardians, } \\
\text { welcoming them. }\end{array}$ & $\begin{array}{l}\text { - Welcoming the family and informed parents regarding } \\
\text { hearing and language development. } \\
\text { - Greater adherence of parents/guardians to the NHS } \\
\text { recommendations and the retest. }\end{array}$ & \\
\hline & & & $\begin{array}{l}\text { - Including the name of the mothers in a control list, } \\
\text { with the address and phone number of those whose } \\
\text { newborns and infants failed the test and will need to be } \\
\text { retested, as well as those who passed the NHS, } \\
\text { but presented RIHL, to be actively sought. }\end{array}$ & $\begin{array}{l}\text { - Ensuring that the retest is performed, as well as the } \\
\text { hearing monitoring }\end{array}$ & \\
\hline
\end{tabular}

Figure 2. Logical Model of the Neonatal Hearing Screening Program (To be continued) 


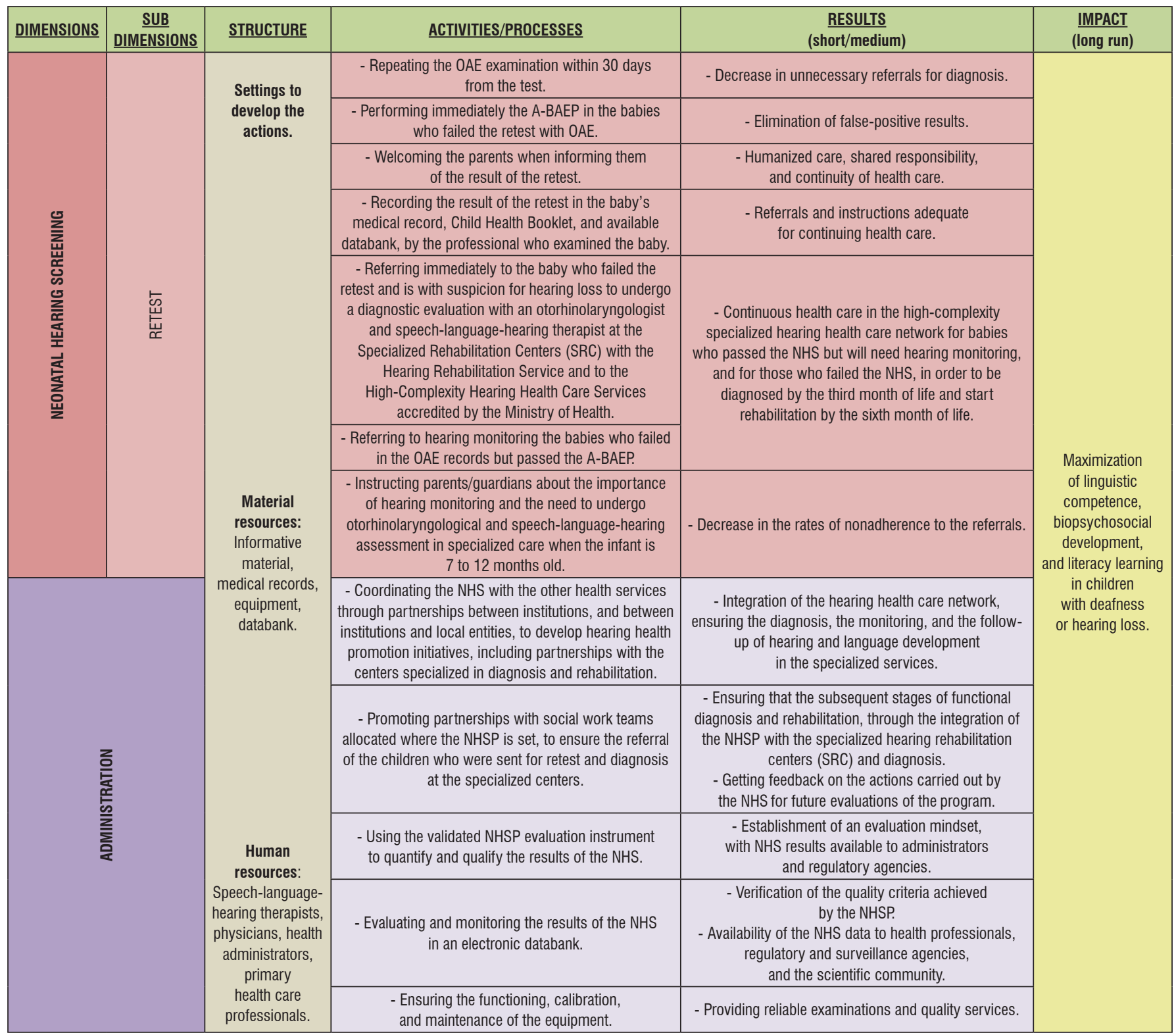

Source: Author of the research (2019).

Figure 2. Logical Model of the Neonatal Hearing Screening Program (Conclusion) 


\section{DISCUSSION}

The proposal of NHSP modelization aims to give support for the periodical evaluations and interventions to follow the logic for which the program was created, instead of merely basing it on hypotheses or implicit knowledge ${ }^{13,18}$.

In this regard, the documentary research was indispensable, as it made it possible to scrutinize every detail of the program in the stages that constitute it.

In the second round of the LM validation, "Hearing monitoring of all neonates and infants with risk indicators for hearing loss (RIHL)" was excluded. This decision is justified, as the NHSP LM in question intends to describe the initial steps of the NHS - i.e., the prevention and detection of hearing loss.

These stages aim to promote educative actions, identification of risks, the performance of the hearing screening at birth, and coordination of NHS with other levels of health care, to ensure the baby an adequate referral and increase the parents' adherence to the referrals to subsequent stages in the program. The subsequent stages are the ones that encompass the hearing monitoring, diagnosis, and rehabilitation in the hearing health network ${ }^{6,25}$.

Therefore, since the hearing monitoring belongs to a post-screening, post-detection stage, the abovementioned variable was excluded from the "Neonatal Hearing Screening" dimension. Monitoring will be mentioned in the logical model when dealing with the baby's referral for follow-up in the specialized network, as recommended in the normative documents - e.g., the Health Care Guidelines in Neonatal Hearing Screening 6,25 .

The specialists' contribution to the dialectical process took place in the face-to-face meeting held to validate the model presented. Moreover, different issues were brought up, such as the inclusion of the subdimensions 1) "Diagnosis of the community" and 2) "Instructive actions" in Education in Hearing Health.

This first point, although not approached in the normative documents, is an advance in NHSP actions.

The suggestion to include "diagnosis of the community" was due to the need to get acquainted with the profile of the community where the NHSP is located, to map the risk indicators for hearing loss (RIHL) in the community. Hence, the epidemiologic, socioeconomic, and demographic profile of the families whose babies were submitted to NHS should be traced to feed the databank. Then, based on the perception of the local needs, the NHSP will be able to direct its research and actions having in view the specificities of that particular population.

In the second point, "instructive actions", the specialists pointed out the need to inform the parents about the importance of immunization to prevent hearing losses, as well as attending prenatal care. Even though the NHS has been mandatory nationwide since 2010, the unawareness of the population is still notorious regarding the examination and its benefits.

Further in "instructive actions", it was discussed the unfeasibility of holding formal meetings or speeches with the relatives and health professionals who work in the setting where the NHS takes place.

It was stated that such activities usually do not produce the expected results because, according to the specialists present at the meeting, the parents do not attend them. For instance, the meetings are held in days and hours different from the prenatal care and, after the baby is born, neonatal nursing. Likewise, the health professionals (greatest partners of the NHS) do not attend the formal meetings due to their intense routine of daily activities, for example.

For the NHS to be successful and for the subsequent stages of diagnosis and rehabilitation to take place, the people involved need to talk - physicians, nurses ${ }^{26}$, community health agents, parents, relatives etc. Hence, to minimize the difficulties in interpersonal and interprofessional dialogue, it was suggested that the speech-language-hearing therapists and physicians directly involved with the NHS conduct these instructive actions. The suggestion was that they take place in conversation circles in the settings where these parents and health professionals usually are (waiting rooms, clinic meetings, and others) for a more efficient exchange of information.

Including this type of activity in the NHS services can narrow the relationship not only with the community but especially with the professionals directly or indirectly involved with the NHSP. Moreover, it is a step toward cooperation with the hearing health care network, as the exchange of information will enable the health professionals to work together with the NHS, providing the necessary instructions to the parents and adequate referrals to the babies ${ }^{26}$.

Having conversation circles with the relatives, besides approaching the prevention and the importance of the NHS to early detect hearing losses, involves the parents in sharing the responsibility. One of the greatest hindrances to the success of the NHSP has been, from its beginning, the parents' and relatives' 
nonadherence to the referrals for retest, diagnosis, or even to start and continue the rehabilitation itself ${ }^{27,28}$.

Thus, the process of developing and validating the logical model of the Neonatal Hearing Screening Program, described in this article, achieved its goal to outline the ideal functioning of the program, scrutinizing every detail in its constituent stages. It is expected that the presentation of a modelization-based evaluative instrument will boost the creation of the National Neonatal hearing Screening Program, the emergence of new government policies, and the establishment of a national databank where epidemiologic data regarding the prevalence of hearing loss in the country can be entered and analyzed, besides identifying the actual contribution the NHSP has been making to the society at large.

The research is admittedly limited for encompassing only specialists from the Northeast Region of Brazil and for having the minimum number of specialists for its validation. Hence, it is suggested that the instrument be administered in the field and, after these experiences, adjustments and new evaluations be made considering the whole set of indicators.

\section{CONCLUSION}

The logical model proposed in this paper was able to expose the dimensions, activities, and results of the Neonatal Hearing Screening Program in practical and clear terms. Hence, it can be useful not only in the process of communicating and announcing its results, but also in offering support for future evaluative research in the field of neonatal hearing health.

Perhaps, the emergence of a modelization-based evaluative instrument will boost the creation of a National Neonatal Hearing Screening Program, new government policies, and a national databank for the storage and analysis of epidemiologic data regarding the prevalence of hearing loss in the country, besides identifying the actual contribution the NHSP has been making to the society at large.

\section{REFERENCES}

1. Sedano MC, Martín UAS, Rahal EM. Realidad nacional de los programas de detección auditiva temprana con miras a la cobertura universal. Rev. Otorrinolaringol. Cir. Cabeza Cuello. 2018;78(1):9-14.

2. Bouillot L, Vercherat $M$, Durand C. Implementing universal newborn hearing screening in the French
Rhône-Alpes region. State of affairs in 2016 and the 1st half of 2017. Int J Pediatr Otorhinolaryngol. 2019;117(1):30-6.

3. Wenjin $\mathrm{W}$, Xiangrong $\mathrm{T}$, Yun L, Jingrong $\mathrm{L}$, Jianyong $C$, Xueling $W$ et al. Neonatal hearing screening in remote areas of China: a comparison between rural and urban populations. JIMR. 2017;46(2):637-51.

4. Fort M. Newborn Hearing Screening: making a difference. NCMJ [serial on the Internet]. 2017 March-April [cited 2019 apr 18]; 78(2): [about 4 p.]. Available from:http://www.ncmedicaljournal.com/ content/78/2/96.full.pdf + html

5. Greczka G, Zych M, Szyfter W, Wróbel M. Analysis of the changes in the Polish Universal Neonatal Hearing Screening Program over 15 years of activity. Otolaryngol Pol. 2018;72(2):13-20.

6. Vieira EP, Miranda EC, Azevedo MF, Garcia MV. Ocorrência dos indicadores de risco para a deficiência auditiva infantil no decorrer de quatro anos em um programa de triagem auditiva neonatal de um hospital público. Rev. soc. bras. fonoaudiol. 2007;12(3):214-20.

7. Brasil, Ministério da Saúde. Diretrizes de Atenção da Triagem Auditiva Neonatal Secretaria de Atenção à Saúde. Departamento de Ações Programáticas Estratégicas e Departamento de Atenção Especializada. Brasília: Ministério da Saúde, 2012a. Disponível em: http://bvsms.saude.gov.br/bvs/ publicacoes/diretrizes_atencao_triagem_auditiva_ neonatal.pdf. Acesso em: 19 set. 2018.

8. Ribeiro FM, Chapchap MJ, Lewis DR. Indicadores de risco para a deficiência auditiva no contexto atual da TANU. In: Boéchat EM, Menezes PL, Couto $\mathrm{CM}$, Frizzo ACF, Scharlach RC, Anastasio ART (orgs). Tratado de Audiologia. 2 ed. Rio de Janeiro: Guanabara Koogan, 2015. p. 381-5.

9. Colella-Santos MF, Souza GL, Hein TAD. Triagem Auditiva Neonatal em UTI. In: Boéchat EM, Menezes PL, Couto CM, Frizzo ACF, Scharlach RC, Anastasio ART (orgs). Tratado de Audiologia. 2 ed. Rio de Janeiro: Guanabara koogan, 2015. p. 386-94.

10. Morettin M, Melo TM, Bevilacqua MC. A avaliação dos serviços de saúde auditiva: o uso de indicadores de qualidade. In: Bevilacqua MC, Martinez MAN, Ballen AS, Pupo AC, Reis ACMB, Frota SMMC (orgs). Saúde Auditiva no Brasil: Políticas, Serviços e Sistemas. 1 ed. São José dos Campos: Pulso Editorial, 2010. p. 119-34.

11. Silva LMV. Metodologia para análise da implantação de processos relacionados à descentralização da atenção à saúde no Brasil. In: Hartz ZMA, Silva LMV 
(orgs). Avaliação em Saúde: dos modelos teóricos à prática na avaliação de programas e sistemas de saúde. Salvador: EDUFBA; Rio de Janeiro: Fiocruz, 2005. p. 207-29.

12. Fontenele RM, Sousa Al, Rasche AS, Souza MHN, Medeiros DC. Construção e validação participativa do modelo lógico do Programa Saúde na Escola. Saúde Debate 2017;41(N. Especial):167-79.

13. Medina MG, Silva GAP, Aquino R, Hartz ZMA. Usos de modelos teóricos na avaliação em saúde: aspectos conceituais e operacionais. In: Hartz ZMA, Vieira-da-Silva LM (orgs). Avaliação em Saúde: dos modelos teóricos à prática na avaliação de programas e sistemas de saúde. 1 ed. Salvador: EDUFBA; Rio de Janeiro: Fiocruz, 2005. p. 41-63.

14. Vitorino SAS, Cruz MM, Barros DC. Validação do modelo lógico teórico da vigilância alimentar e nutricional na atenção primária em saúde. Cad. Saúde Pública. 2017;33(12):e00014217.

15. Mclaughlin JA, Jordan GB. Using Logic Models. In: Newcomer KE, Hatry HP, Wholey JS (eds). Handbook of practical program evaluation. 4th ed. San Francisco: Jossey-Bass; 2015. p. 62-87.

16. Champagne F, Brousselle A, Harz Z, Contandriopoulos AP. Modelizar as intervenções. In: Brousselle A, Champagne F, Contandriopoulos AP, Harz Z (orgs). Avaliação: conceitos e métodos. Rio de Janeiro: Editora Fiocruz, 2011b. p. 61-74.

17. Oliveira CM, Cruz MM, Kanso S, Reis AC, Lima A, Torres RMC et al. Evaluability of the Program to Value Primary Healthcare Professionals (PROVAB): management challenges. Ciênc. Saúde Coletiva. 2015;20(10):2999-3010.

18. Bezerra TCA, Falcão MLP, Goes PSA, Felisberto E. Avaliação de programas de formação profissional em saúde: construção e validação de indicadores. Trab. Educ. Saúde 2016;14(2):445-72.

19. Silva RN, Guarda FRB, Hallal PC, Martelli PJL. Avaliabilidade do Programa Academia da Saúde no Município do Recife, Pernambuco, Brasil. Cad. Saúde Pública. 2017;33(4):e 00159415.

20. Souza LEPF, Silva LMV, Hartz ZMA. Conferência de consenso sobre a imagem-objetivo da descentralização da atenção à saúde no Brasil. In: Hartz ZMA, Silva LMV (orgs). Avaliação em Saúde: dos modelos teóricos à prática na avaliação de programas e sistemas de saúde. Salvador: EDUFBA; Rio de Janeiro: Fiocruz, 2005. p. 65-91.

21. Almeida MHM, Spínola AWP, Lancman S. Técnica Delphi: validação de um instrumento para uso do terapeuta ocupacional em gerontologia. Rev. Ter. Ocup. Univ. São Paulo. 2009;20(1):49-58.
22. Aragão AAV, Oliveira SRA, Gurgel Júnior GD. The use of the Delphi Method adjusted to evaluate the Stork Network: from Image-objective to reality. Esc Anna Nery [serial on the Internet] 2019 Mar [cited 2019 jul 18]; 23(2):[about 8 p.]. Available from: http://www.revenf.bvs.br/pdf/ean/v23n2/pt_14148145-ean-23-02-e20180318.pdf

23. Pasquali L. Princípios de elaboração de escalas psicológicas. Revista de Psicologia Clínica. 1998;25(5):206-13.

24. Lynn MR. Determination and quantification of content validity. Nursing research. 1986;35(6):382-6.

25. Lewis DR, Marone SAM, Mendes BCA, Cruz OLM, Nóbrega M. Comitê multiprofissional em saúde auditiva (COMUSA). Braz J Otorhinolaryngol. 2010;76(1):121-8.

26. Molina ASH, Sinchiguano GED, Cabezas CCC, Rivadeneira MER. Enfermería en la atención multidisciplinaria de la hipoacusia neonatal. REE [serial en Internet]. $2018 \mathrm{Jul}$ [acceso en 2019 mai 15];12(2): [número aproximado de páginas 13 p.]. Disponible en: http://eugenioespejo.unach.edu.ec/ index.php/EE/article/view/72/96

27. Malheiros MASF, Cavalcanti HG. Characterization of newborn hearing screening programs of maternity units located in the city of João Pessoa, PB, Brazil - PB. Rev. CEFAC. 2015;17(2):454-60.

28. Dantas MBS, Anjos CAL, Camboim ED, Pimentel MCR. Resultados de um programa de triagem auditiva neonatal em Maceió. Rev Bras Otorrinolaringol. 2009;75(1):58-63.

\section{Erratum}

In the article, "Development and validation of the Logical Model of the Neonatal Hearing Screening Program", with DOI number: $10.1590 / 1982-0216 / 202022414019$, published in the journal Revista Cefac 2020;22(4):e14019, in Figure 1 (page 3):

\section{Where it was:}

The figure with the text in the wrong language.

\section{Read:}

The figure with the text in the correct language. 